\title{
Continental brines and evaporites of the northern Great Plains of Canada
}

\author{
WILLIAM M. LAST \\ Department of Geological Sciences, University of Manitoba, Winnipeg, Manitoba, R3T 2N2 (Canada)
}

Received September 10, 1987; revised version received March 1, 1988

\begin{abstract}
Last, W.M., 1989. Continental brines and evaporites of the northern Great Plains of Canada. In: R.W. Renaut (Editor), Sedimentology and Diagenesis of Evaporites. Sediment. Geol., 64: 207-221.

The northern Great Plains of western Canada contain millions of saline and hypersaline lakes. Although many of the lakes are dominated by $\mathrm{Na}$ and $\mathrm{SO}_{4}$, there is considerable diversity in ionic composition, and nearly every major water type is represented. This chemical diversity gives rise to a surprisingly complex suite of endogenic and authigenic minerals. A wide variety of sodium and magnesium sulfates, carbonates, chlorides, and silicates are present in the modern and Holocene sediments of the lakes. Four distinct types of evaporites can be identified: (a) crusts and hardgrounds, (b) massive and bedded salts, (c) spring deposits, and (d) subsurface and groundwater-related accumulations. The processes responsible for deposition and diagenesis of these evaporites are variable depending mainly on the morphology of the basin and the brine chemistry.
\end{abstract}

\section{Introduction}

Salt lakes occur on every continent and are nearly equal, in terms of volume, to freshwater lakes. Within the past several decades, saline lake environments have attracted considerable scientific interest. A great deal of this research has been centered on the biological aspects of these lakes; unfortunately the sedimentary processes and deposits have been less intensively studied.

The northern Great Plains of western Canada and United States contain an estimated 3.5 million lakes and another 6-8 million "sloughs". Most of these water bodies are brackish $(1000-5000 \mathrm{mg} / 1)$ or saline $(>5000 \mathrm{mg} / \mathrm{l})$. Indeed, in large areas of the region, high-salinity lacustrine brines are the only permanent surface water present. Our knowledge of the character and variability of these continental brine systems and the processes responsible for deposition and diagenesis of the lacustrine sediments has advanced in recent years. The purpose of this paper is to provide an overview of the chemical characteristics of the lacustrine brines and the sedimentological nature of the evaporites in these basins.

\section{Setting}

The northern Great Plains, a vast region of over $350,000 \mathrm{~km}^{2}$, is the agricultural heartland of Canada and also contains most of the population of western Canada. The region is characterized by flat to gently rolling topography and experiences a cold, semi-arid climate. Pleistocene continental glaciation has resulted in a thick mantle of unconsolidated glacial, glaciofluvial, and glaciolacustrine sediment overlying the generally flat-lying Cretaceous and Tertiary bedrock.

From the standpoint of salt lake development and evaporite mineral formation, the two most important physical features of the region are high evaporation/precipitation ratios and the presence 
of large areas of endoreic drainage. Although the mean annual temperature of about $3^{\circ} \mathrm{C}$ would imply relatively low evaporation rates, the high winds, low humidity, and warm summer temperatures create evaporation/precipitation ratios of generally between 3 and 10 . These climatic features, combined with the poorly integrated drainage, in which nearly a third of southern Saskatchewan and eastern Alberta is topographically closed, result in a large number of saline lakes of diverse morphologies and sedimentary characteristics.

\section{Chemical nature of the brines}

In addition to a number of published reports of water composition of individual basins scattered throughout the prairies, there have also been several attempts to summarize the chemistry of lakes on the Great Plains from a regional perspective. Early studies by Clarke (1924), Cole (1926), Rawson and Moore (1944), and Grossman (1949) emphasized that the salt lakes are dominated by sodium and sulfate. More recently, Rutherford
(1970), Winter (1977), Hammer (1978), Cameron (1986), and Last (1988) have recognized several main classes of water types and have related spatial variation to individual basin morphology, climatic gradients, and groundwater composition.

Of the millions of salt lakes in the Canadian Plains region, water chemistry data exists for only about 400 basins (Fig. 1). Even from this relatively small sampling, several general observations can be made:

(1) The lakes show a great range in concentrations, from relatively dilute water $(<10$ ppt TDS) to brines greater than an order of magnitude more concentrated than normal seawater. The "average" lake of the region has a salinity of about $31 \mathrm{ppt}$ TDS.

(2) Although the lakes are dominated by only a few major ions $\left(\mathrm{Na}^{+}, \mathrm{Mg}^{2+}, \mathrm{Ca}^{2+}, \mathrm{SO}_{4}^{2-}, \mathrm{Cl}^{-}\right.$, and $\mathrm{HCO}_{3}^{-}$), these major solutes exhibit a considerable range in concentrations and relative proportions. Nearly every major water composition type is represented in these lakes (Fig. 2). Sulfate and carbonate-rich lakes clearly dominate the anion field comprising over $95 \%$ of the total lakes.

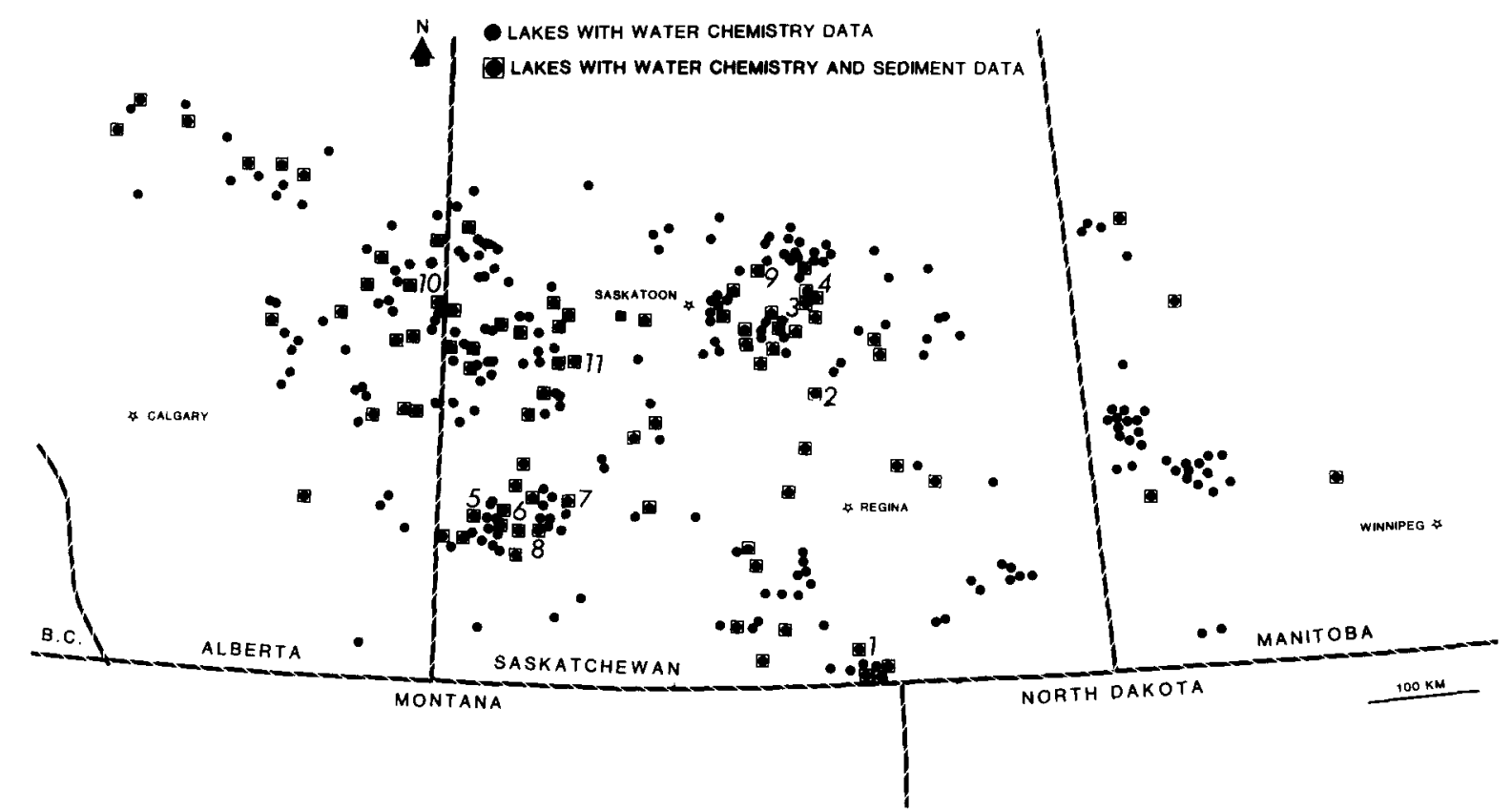

Fig. 1. Map showing the locations of salt lakes in the northern Great Plains of western Canada for which water chemistry and sediment data exist. The symbols indicate approximate location only and are not meant to reflect basin size or morphology. The numbers show the locations of the lakes specifically referred to in the text: $1=$ Ceylon; $2=$ Little Manitou; $3=$ Waldsea; $4=$ Deadmoose; $5=$ Ingebright; $6=$ Freefight; $7=$ Verlo; $8=$ Corral; $9=$ Muskiki; $10=$ Metiskow; $11=$ Lydden. 


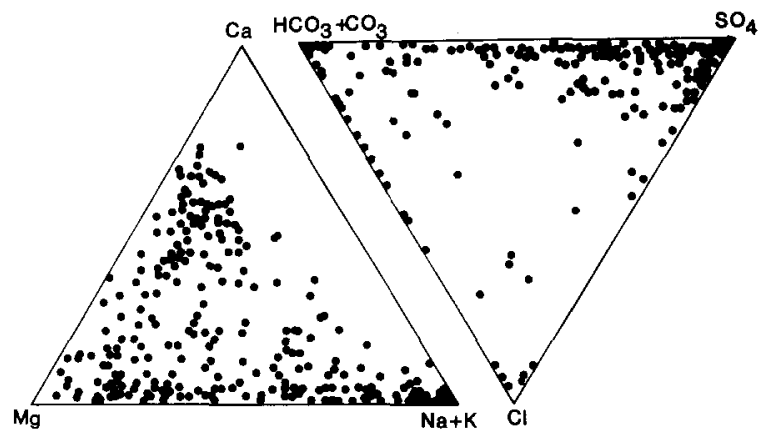

Fig. 2. Triangular diagram showing the water composition (percent equivalents) of 379 saline lakes in the northern Great Plains of western Canada. Compiled from numerous sources (see text).

The cation ratios are much more diverse with the abundance of all three major types showing approximately subequal proportions. While the "average" salt lake is dominated by sodium and sulfate $\left(\mathrm{Na}>\mathrm{Mg}>\mathrm{Ca}>\mathrm{K} ; \mathrm{SO}_{4}>\mathrm{Cl}>\mathrm{HCO}_{3}>\right.$ $\mathrm{CO}_{3}$ ), because of the great range of compositions it is clearly misleading to characterize all the lacustrine brines of the Great Plains as having a $\mathrm{Na}-\mathrm{SO}_{4}$ dominance.

(3) Most of the solutes in the lake waters increase in concentration with increasing total salinity. Sodium, magnesium, sulfate, and chloride ions show the best correlation with TDS, while calcium, potassium, and bicarbonate + carbonate concentrations are less directly related to salinity. The proportions of some of the solutes also show a systematic change with salinity. Sodium and sulfate increase in relative ionic proportion from less than $30 \%$ equivalents in relatively dilute lakes ( $<10$ ppt TDS) to generally more than $90 \%$ in lakes with more than 100 ppt TDS. Calcium and bicarbonate + carbonate proportions show an inverse relationship with salinity, decreasing from over $70 \%$ equivalents in the dilute waters to less than $10 \%$ in the more concentrated brines.

Any attempt to generalize and characterize the lacustrine brines of the Great Plains must cope with the vast range of geographic, geomorphic, and climatic conditions which exist in this large region. Thus, one would expect differences in the chemistry of water bodies in areas as diverse as the Manitoba Lowlands, the Sandhills of southwestern Saskatchewan, and the hummocky ground moraine area of central Alberta. Table 1 summarizes the major ion chemistry of lakes in selected geographic areas of the Plains.

Another complicating factor is that many of the salt lakes occupy shallow basins. Last and Schweyen (1983) estimate that $85 \%$ of the salt lakes of the region are less than $3 \mathrm{~m}$ deep. This means that many of the lakes exhibit playa characteristics: filling with water during the spring and early summer and drying during the late summer. This strong seasonality of water levels gives rise to dramatic changes in both ion concentrations and ratios, as demonstrated by numerous studies

TABLE 1

Mean brine composition of lakes in selected areas of the northern Great Plains (ion concentrations in mmol/l)

\begin{tabular}{|c|c|c|c|c|c|c|c|c|c|}
\hline $\begin{array}{l}\text { Area and } \\
\text { number of lakes }\end{array}$ & $\begin{array}{l}\text { TDS } \\
\text { (ppt) }\end{array}$ & $\mathrm{Ca}$ & $\mathrm{Mg}$ & $\mathrm{Na}$ & $\mathrm{K}$ & $\mathrm{HCO}_{3}$ & $\mathrm{CO}_{3}$ & $\mathrm{Cl}$ & $\mathrm{SO}_{4}$ \\
\hline \multicolumn{10}{|c|}{ Western Manitoba and } \\
\hline \multicolumn{10}{|c|}{ Eastern Saskatchewan } \\
\hline (63 lakes) & 2.6 & 3.6 & 23.6 & 4.1 & 0.8 & 6.1 & 0.7 & 2.1 & 23.8 \\
\hline \multicolumn{10}{|c|}{ Central Saskatchewan } \\
\hline (139 lakes) & 22.0 & 18.7 & 149.1 & 192.9 & 5.1 & 7.2 & 2.5 & 53.7 & 250.8 \\
\hline \multicolumn{10}{|c|}{ Southwestern Saskatchewan } \\
\hline \multicolumn{10}{|c|}{ and Southeastern Alberta } \\
\hline (82 lakes) & 80.6 & 11,9 & 92.8 & 1087.8 & 4.1 & 96.1 & 35.9 & 28.7 & 1072.7 \\
\hline \multicolumn{10}{|c|}{$\begin{array}{l}\text { West-central Saskatchewan } \\
\text { and east-central Alberta }\end{array}$} \\
\hline (121 lakes) & 102.5 & 3.4 & 143.8 & 1361.9 & 9.6 & 268.0 & 44.3 & 107.4 & 1124.7 \\
\hline
\end{tabular}


(Moore, 1939; White and Hartland-Rowe 1969; Rozkowska and Rozkowski, 1969; Barica, 1975; Driver and Peden, 1977; Schwartz and Gallup, 1978; Last, 1984, 1989).

\section{Description of salt lake evaporites}

Of the approximately 400 basins in the northern Great Plains for which water chemistry has

TABLE 2

Mineralogy and mode of occurrence of endogenic and authigenic precipitates in saline lake environments of the northern Great Plains $^{a}$

\begin{tabular}{|c|c|c|c|c|}
\hline \multirow[t]{2}{*}{ Mineral } & \multicolumn{4}{|c|}{ Mode of occurrence } \\
\hline & $\begin{array}{l}\text { crusts and } \\
\text { hardgrounds }\end{array}$ & $\begin{array}{l}\text { massive and } \\
\text { bedded ppt. }\end{array}$ & $\begin{array}{l}\text { spring } \\
\text { deposits }\end{array}$ & $\begin{array}{l}\text { subsurface and } \\
\text { groundwater ppt. }\end{array}$ \\
\hline ARAGONITE $\mathrm{CaCO}_{3}$ & $\mathrm{x}$ & $\mathrm{X}$ & $\mathrm{x}$ & $\mathrm{x}$ \\
\hline CALCITE $\mathrm{CaCO}_{3}$ & $\mathrm{x}$ & $\mathrm{x}$ & $\mathrm{X}$ & \\
\hline MAGNESIAN CALCITE $\mathrm{CaCO}_{3}$ & $\mathrm{x}$ & $\mathrm{x}$ & $\mathrm{X}$ & \\
\hline Dolomite $\mathrm{CaMg}\left(\mathrm{CO}_{3}\right)_{2}$ & $\mathrm{x}$ & $X$ & & $\mathbf{x}$ \\
\hline Protodolomite $\mathrm{CaMg}\left(\mathrm{CO}_{3}\right)_{2}$ & $\mathbf{x}$ & $\mathrm{X}$ & $\mathrm{x}$ & $x$ \\
\hline Huntite $\mathrm{CaMg}_{3}\left(\mathrm{CO}_{3}\right)_{4}$ & $\mathrm{X}$ & $\mathrm{x}$ & & $\mathrm{X}$ \\
\hline Magnesite $\mathrm{MgCO}_{3}$ & $\mathrm{x}$ & $\mathrm{X}$ & & \\
\hline Nesquehonite $\mathrm{Mg}\left(\mathrm{HCO}_{3}\right)\left(\mathrm{CO}_{3}\right)_{4}$ & $\mathrm{X}$ & $\mathrm{x}$ & & $\mathrm{x}$ \\
\hline Nahcolite $\mathrm{NaHCO}_{3}$ & $X$ & & & \\
\hline Natron $\mathrm{Na}_{2} \mathrm{CO}_{3} \cdot 10 \mathrm{H}_{2} \mathrm{O}$ & & $\mathrm{X}$ & & \\
\hline Trona $\mathrm{NaHCO}_{3} \cdot \mathrm{Na}_{2} \mathrm{CO}_{3} \cdot 2 \mathrm{H}_{2} \mathrm{O}$ & & $X$ & & \\
\hline Siderite $\mathrm{FeCO}_{3}$ & & $\mathrm{x}$ & & $\mathrm{X}$ \\
\hline Scarbroite $\mathrm{Al}_{2}\left(\mathrm{CO}_{3}\right)_{3} \cdot 13 \mathrm{Al}(\mathrm{OH})_{3}$ & & & & $\mathrm{X}$ \\
\hline Dawsonite $\mathrm{NaAl}\left(\mathrm{CO}_{3}\right)(\mathrm{OH})_{2}$ & & & & $\mathrm{X}$ \\
\hline GYPSUM CaSO $4 \cdot 2 \mathrm{H}_{2} \mathrm{O}$ & $X$ & $\mathbf{x}$ & $\mathrm{x}$ & $\mathrm{X}$ \\
\hline MIRABILITE $\mathrm{Na}_{2} \mathrm{SO}_{4} \cdot 10 \mathrm{H}_{2} \mathrm{O}$ & $\mathrm{X}$ & $\mathrm{X}$ & $\mathrm{X}$ & $\mathrm{X}$ \\
\hline THENARDITE $\mathrm{Na}_{2} \mathrm{SO}_{4}$ & $\mathrm{X}$ & $\mathrm{x}$ & $\mathrm{x}$ & $\mathrm{x}$ \\
\hline BLOEDITE $\mathrm{Na}_{2} \mathrm{Mg}\left(\mathrm{SO}_{4}\right)_{2} \cdot 4 \mathrm{H}_{2} \mathrm{O}$ & $x$ & $\mathbf{x}$ & $\mathrm{x}$ & \\
\hline Loeweite $\mathrm{Na}_{12} \mathrm{Mg}_{7}\left(\mathrm{SO}_{4}\right)_{13} \cdot 15 \mathrm{H}_{2} \mathrm{O}$ & $\mathbf{X}$ & & & \\
\hline Konyaite $\mathrm{Na}_{2} \mathrm{Mg}\left(\mathrm{SO}_{4}\right)_{2} \cdot 5 \mathrm{H}_{2} \mathrm{O}$ & $\mathrm{X}$ & & & \\
\hline Eugsterite $\mathrm{Na}_{4} \mathrm{Ca}\left(\mathrm{SO}_{4}\right)_{3} \cdot 2 \mathrm{H}_{2} \mathrm{O}$ & $\mathrm{X}$ & & & \\
\hline D'Ansite $\mathrm{Na}_{21} \mathrm{Mg}\left(\mathrm{SO}_{4}\right)_{10} \mathrm{Cl}_{3}$ & $\mathrm{x}$ & & & $\mathrm{X}$ \\
\hline Kieserite $\mathrm{MgSO}_{4} \cdot \mathrm{H}_{2} \mathrm{O}$ & $X$ & & & \\
\hline Hexahydrite $\mathrm{MgSO}_{4} \cdot 6 \mathrm{H}_{2} \mathrm{O}$ & $\mathrm{x}$ & & & $\mathrm{X}$ \\
\hline EPSOMITE $\mathrm{MgSO}_{4} \cdot 7 \mathrm{H}_{2} \mathrm{O}$ & $\mathrm{X}$ & $\mathbf{x}$ & $\mathrm{X}$ & $\mathrm{x}$ \\
\hline Burkeite $\mathrm{Na}_{2} \mathrm{CO}_{3} \cdot 2 \mathrm{Na}_{2} \mathrm{SO}_{4}$ & $X$ & & & $\mathrm{x}$ \\
\hline Tychite $\mathrm{Na}_{6} \mathrm{Mg}_{2}\left(\mathrm{CO}_{3}\right)_{4} \mathrm{SO}_{4}$ & $x$ & & & \\
\hline Jarosite $\mathrm{KFe}_{3}\left(\mathrm{SO}_{4}\right)_{2}(\mathrm{OH})_{6}$ & $\mathrm{x}$ & & & $\mathrm{X}$ \\
\hline Natrojarosite $\mathrm{NaFe}_{3}\left(\mathrm{SO}_{4}\right)_{2}(\mathrm{OH})_{6}$ & $\mathrm{x}$ & & & \\
\hline Halite $\mathrm{NaCl}$ & $\mathrm{X}$ & $\mathbf{x}$ & $\mathrm{x}$ & $\mathrm{x}$ \\
\hline Hydrohalite $\mathrm{NaCl} \cdot 2 \mathrm{H}_{2} \mathrm{O}$ & & $\mathrm{x}$ & $X$ & \\
\hline PYRITE FeS ${ }_{2}$ & & $\mathbf{x}$ & & $\mathrm{X}$ \\
\hline Greigite $\mathrm{Fe}_{3} \mathrm{~S}_{4}$ & & & & $\mathrm{X}$ \\
\hline Carbonate-apatite $\mathrm{Ca}_{5}\left(\mathrm{PO}_{4}, \mathrm{CO}_{3}\right)_{3}(\mathrm{OH})$ & & $\mathrm{x}$ & & $\mathrm{X}$ \\
\hline Sepiolite $\mathrm{Mg}_{4} \mathrm{Si}_{6} \mathrm{O}_{15}(\mathrm{OH})_{2} \cdot \mathrm{H}_{2} \mathrm{O}$ & & $\mathbf{X}$ & & $\mathbf{x}$ \\
\hline Smectite hydrous $\mathrm{Mg}-\mathrm{Fe}$ aluminosilicate & & $\mathrm{X}$ & & $\mathrm{x}$ \\
\hline Norstrandite $\mathrm{Al}(\mathrm{OH})_{3}$ & & & & $X$ \\
\hline Goethite FeO(OH) & & & & $X$ \\
\hline Diaspore $\mathrm{AlO}(\mathrm{OH})$ & & & & $\mathrm{X}$ \\
\hline Rancieite $(\mathrm{Ca}, \mathrm{Mn}) \mathrm{Mn}_{4} \mathrm{O}_{9} \cdot 3 \mathrm{H}_{2} \mathrm{O}$ & & & $\mathrm{X}$ & \\
\hline
\end{tabular}

a Print size varied to indicate frequency of occurrence. 
been documented, we have knowledge of the sediments in only about a third (Fig. 1). Similar to the early studies of brine composition, initial sedimentological efforts (e.g., Cole, 1926; Grossman, 1949, 1968; Binyon, 1952; Tomkins, 1953, 1954) stressed the dominance of sodium sulfate salts and were directed mainly toward basins with large reserves of economically important industrial minerals. We now realize that the lakes exhibit a complete spectrum of sediment types, from basins dominated by allogenic or clastic material to those in which relatively pure, clastic-free evaporites are forming.

The evaporite minerals found in the sediments of the salt lakes are listed in Table 2. Sulfates and evaporite-related carbonates dominate the modern endogenic component of most of the basins, although more rarely silicates and chlorides have been identified. Our limited knowledge of the postglacial sequences in these evaporitic basins reveals an equally diverse mineral assemblage.

Four basic types of evaporite mineral occurrences can be differentiated on the basis of stratigraphic and genetic criteria: (a) crusts and hardgrounds, (b) massive and bedded salts, (c) spring deposits, and (d) subsurface and groundwater-related accumulations.

\section{Crusts and hardgrounds}

Surficial efflorescent crusts and hardgrounds are mineralogically and texturally the most complex occurrences of salts in the region. Efflorescent crusts are found associated with virtually all of the salt lakes but can also form on hillsides and in other non-lacustrine depositional settings. When associated with the salt lakes they are most frequently found covering the marginal mudflats and sandflats of the basins. They are usually thin (1-5 $\mathrm{mm}$ ), but can vary greatly from less than a millimeter to several tens of centimeters in thickness. The exposed surface of the crusts are often soft, friable and ragged (Fig. 3), and easily eroded by wind and rainwash. Internally, the thicker crusts can be porous and hard.

Unlike the monomineralic efflorescent crusts reported from salt lake environments elsewhere (e.g., Eugster and Hardie, 1978; Goudie and Cooke, 1984), the crusts of the northern Great Plains' lakes are seldom composed of only one evaporite mineral. In any single salt efflorescence associated with the lakes, a variety of $\mathrm{Na}$ and $\mathrm{Mg}$ sulfates can commonly occur (Table 2). Mineralogical characterization of these crusts is further complicated by seasonal changes brought about

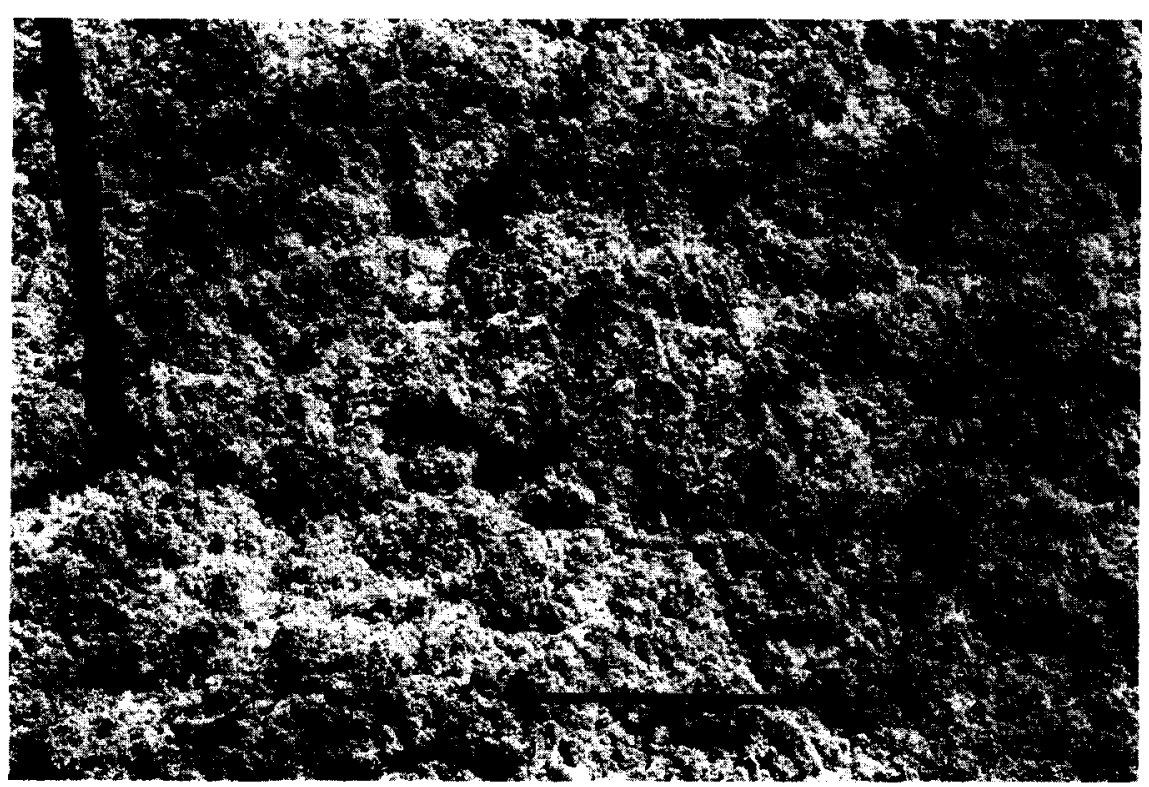

Fig. 3. Efflorescent crust from the marginal mudflat at Verlo Lake, Saskatchewan. Crust is about $10 \mathrm{~cm}$ thick. Scale bar is $10 \mathrm{~cm}$ long. 


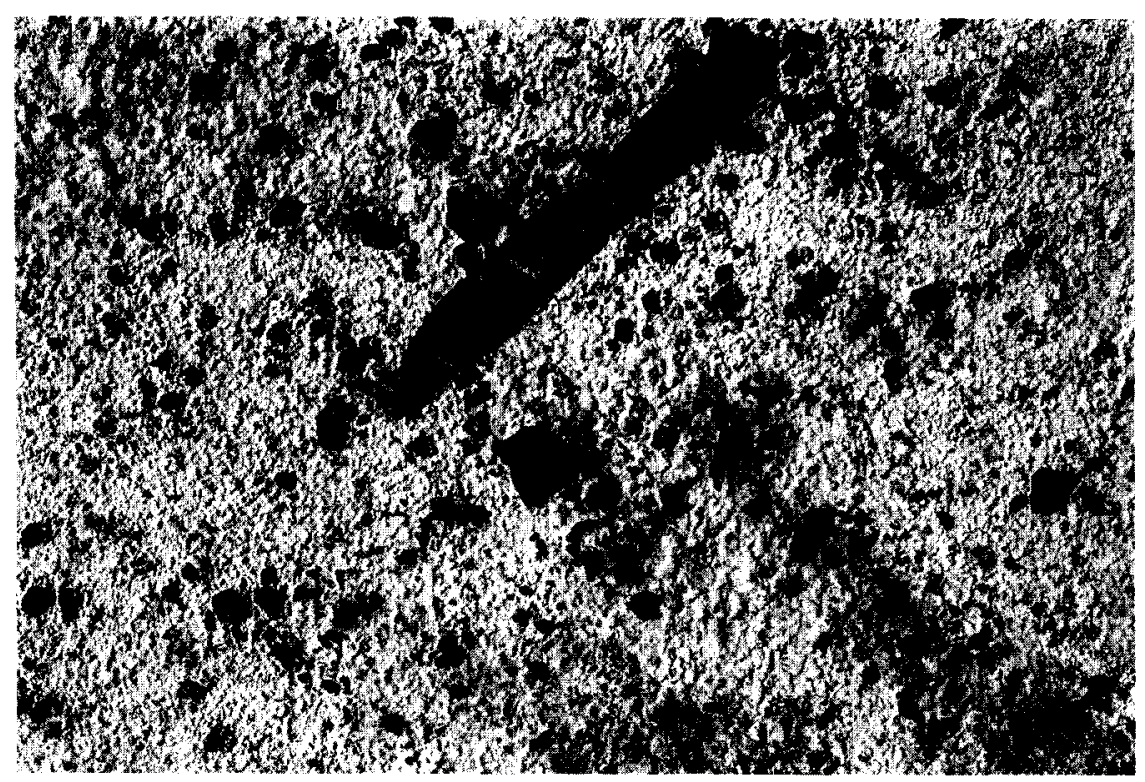

Fig. 4. Surface of mudflat at Freefight Lake, Saskatchewan, showing fragmented carbonate hardground. Knife is $30 \mathrm{~cm}$ long. The hardground is composed of sand and silt-sized quartz grains cemented by aragonite and dolomite (protodolomite).

by the dramatic temperature and humidity fluctuations throughout the year which significantly affect mineral solubilities (Keller et al., 1986; Timpson et al., 1986; Timpson and Richardson, 1986).

Hardgrounds or lithified surface crusts are not as common as efflorescent crusts in the salt lakes of the Great Plains. Where they do occur they tend to be thin and easily broken up into small centimeter-sized plates (Fig. 4). These plates can then be re-cemented to form lithified breccias. Both cemented and uncemented coarse clastic units composed mainly of fragmented hardgrounds occur as modern shoreline deposits in the lakes and have also been reported from the mid-Holocene of Waldsea and Deadmoose lakes in central Saskatchewan (Last and Schweyen, 1985; Last and Slezak, 1986).

The most commonly precipitated cement in the hardgrounds is carbonate. Depending on the specific $\mathrm{Mg} / \mathrm{Ca}$ ratio, sulfate content and salinity of the pore water, these carbonate cements range from calcite and high-magnesium calcite to aragonite, dolomite and, more rarely, magnesite (Fig. 5). Similarly, crystal size and morphology are highly variable. In addition to carbonate-cemented hardgrounds, surface crusts and lithified horizons composed of other authigenic precipitates, such as gypsum and mirabilite, occur in association with some of the salt lakes.

The modern hardgrounds are not associated with any specific facies within the saline lakes. They have been found in both subaerial settings (exposed mudflats, sandflats, and beaches) and

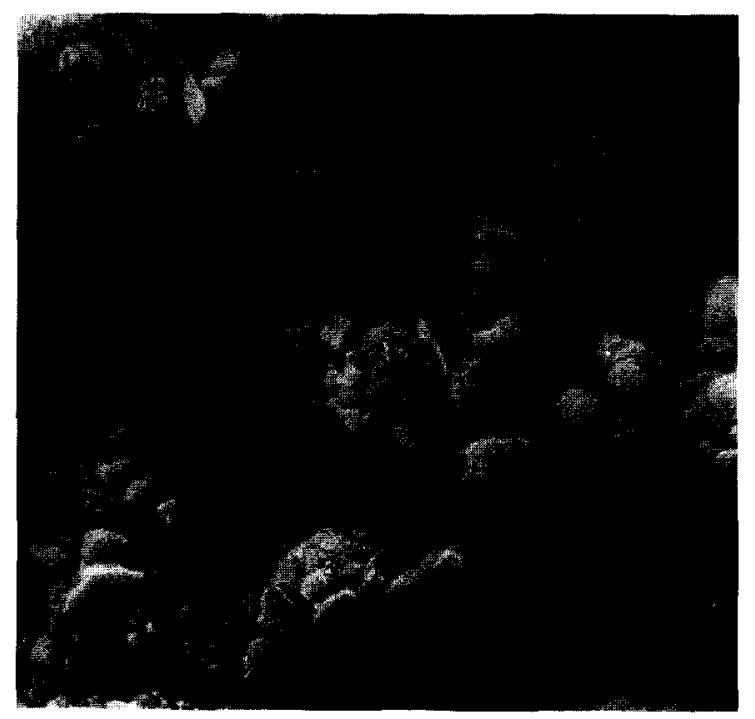

Fig. 5. Scanning electron photomicrograph of hardground cement from Freefight Lake, Saskatchewan. Spherule aggregates of crystals $(D)$ are dolomite/protodolomite(?); acicular euhedral crystals $(A)$ are aragonite. Field of view is $40 \mu \mathrm{m}$. 
subaqueous environments (water depths from less than $1 \mathrm{~m}$ to greater than $20 \mathrm{~m}$ ). It is evident that these hardgrounds are not all genetically related. Some appear to be formed by straightforward inorganic cementation due to evaporative concentration of pore water in the vadose environment. Others are obviously related to organic (cyanobacteria and blue-green algae) processes, while still others may be forming in response to mixing of different water types or to $\mathrm{pH}-\mathrm{Eh}$ changes at the sediment-water interface.

\section{Massive and bedded salts}

Because of their importance as a source of industrial minerals, the massive and thickly bedded evaporites of the playas of the Great Plains have been extensively drilled and studied (Govett, 1958; Rueffel, 1968; Broughton, 1984; Slezak and Last, 1985). The salts which form this resource base are dominantly $\mathrm{Na}$ and $\mathrm{Mg}$ sulfates (mainly mirabilite, thenardite, and epsomite). In detail, however, the mineralogy of individual deposits can be quite complex (Cole, 1926; Last, 1989).

Other than indistinct bedding features, the salts record little original (primary) depositional fabrics or textures. They tend to be uniformly coarsely crystalline and equigranular, and show an interlocking crystalline mosaic texture. Individual crystals usually have few inclusions. Even in very muddy sections of the salt column the insoluble material is concentrated at the crystal boundaries, suggesting repeated dissolution-reprecipitation. Crude horizontal bedding in these otherwise massive salts is most frequently brought about by changes in concentrations of clays and other insolubles. In some cases bedding can also be due to compositional differences, changes in crystal morphology and orientation, or variation in degree of compaction and crystal intergrowth.

These evaporites, which can attain thicknesses in excess of $45 \mathrm{~m}$, are generally viewed as originating from shallow water, playa-salt pan environments. Recently, a second type of depositional setting has been recognized - the deep, meromictic salt lake. While it has been known for some time that many perennial salt lakes of the region exhibit massive $\mathrm{Na}$ and $\mathrm{Mg}$ sulfate mineral precipitation due to freeze-out phenomena (Rawson and
Moore, 1944; Hammer, 1978), it has been tacitly assumed that these soluble salts were put back into solution upon warming of the lake brines during summer. Indeed, this type of freeze-out precipitation-re-solution does seem to be operating in many of the "intermediate" depth (1-3 m) perennial salt lakes of the region today (see table 3 in Last and Schweyen, 1983). However, in some of the deeper lakes and particularly in hypersaline meromictic basins, seasonal salt precipitation does occur but not all of the precipitate is re-dissolved, thereby giving rise to a deep-water, subaqueous salt accumulation.

Compared to the shallow, playa basin salts, relatively little is known about these deep-water deposits. Freefight, Deadmoose, and Little Manitou lakes all have deep-water salt deposits (Last and Schweyen, 1983; Last and Slezak, 1987b, 1988). In contrast to deep-water gypsum and halite accumulations reported elsewhere, the $\mathrm{Na}$ and $\mathrm{Mg}$ sulfate salts that are accumulating in these deep lakes are coarsely crystalline and only poorly bedded. Individual euhedral crystals up to $10 \mathrm{~cm}$ in diameter have been retrieved from the modern bottom sediment at depths greater than $20 \mathrm{~m}$ in Freefight and Deadmoose lakes (Fig. 6). From limited core recovery, these evaporites exhibit both large-scale, indistinct bedding and irregular fine lamination. The coarse banding, represented by regular centimeter-scale alteration of light- and dark-coloured crystal, is due to variable mud and organic matter contents. The fine, irregularly spaced laminae are composed mainly of organic debris and clay minerals with minor gypsum and aragonite.

In addition to these very soluble salts, some of the deep saline lakes also contain a variety of evaporite-related sparingly soluble carbonate and sulfate minerals. Precipitation of calcite and highmagnesium calcite, due mainly to evaporative concentration, is well known from numerous lakes in the region (Callender, 1968; Forbes and Hickman, 1981; MacDonald, 1982; Last, 1982; GhebreEgziabhier and St. Arnaud, 1983a, b; Hickman et al., 1984). The generation of millimeter-scale aragonite-organic clay couplets in Waldsea and Deadmoose lakes have been attributed to periodic carbonate whitings in lakes of moderate salinity 


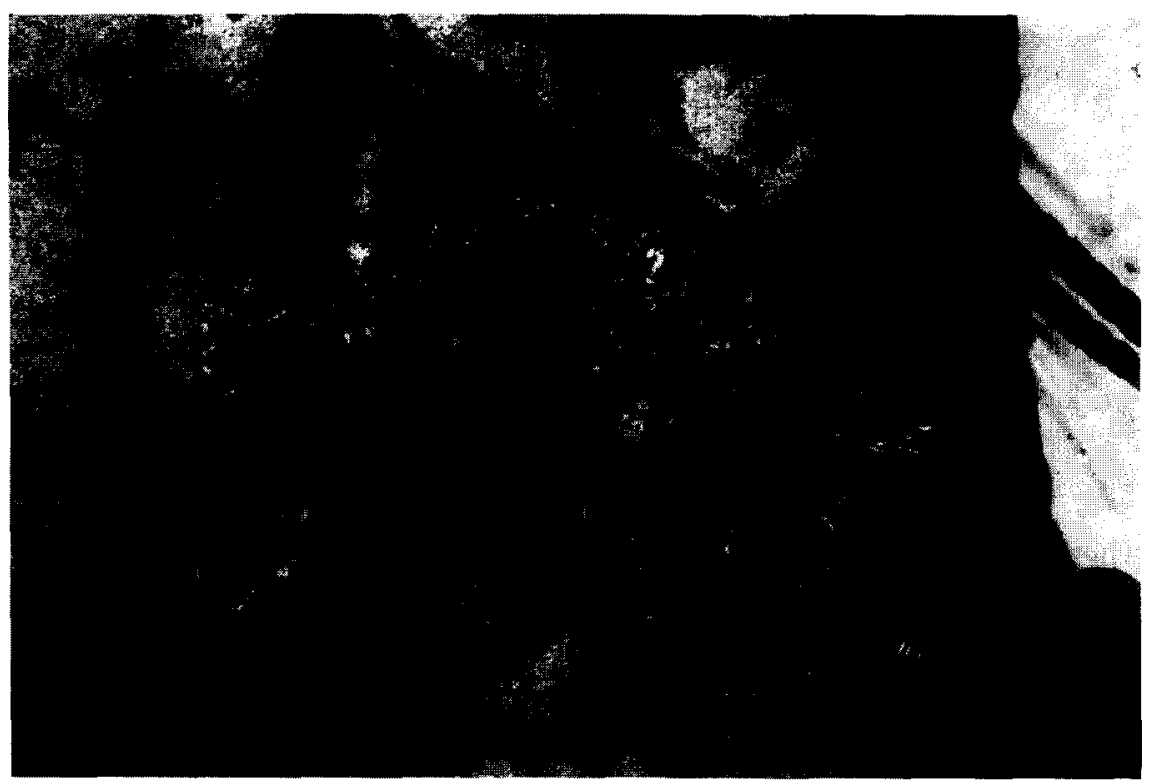

Fig. 6. Modern offshore bottom sediment from Deadmoose Lake, Saskatchewan, from $29 \mathrm{~m}$ depth. Sediment consists mainly of large, equant crystals and crystalline aggregates of mirabilite with minor amounts of organic matter, pyrite, and clay minerals. Lens cap is 5 cm wide.

(40-60 ppt TDS). In contrast, the gypsumcarbonate laminae (which include aragonite, magnesite, and dolomite) in these two lakes probably originated from brines of considerably higher salinity (Last and Schweyen, 1985; Last and Slezak, 1986).

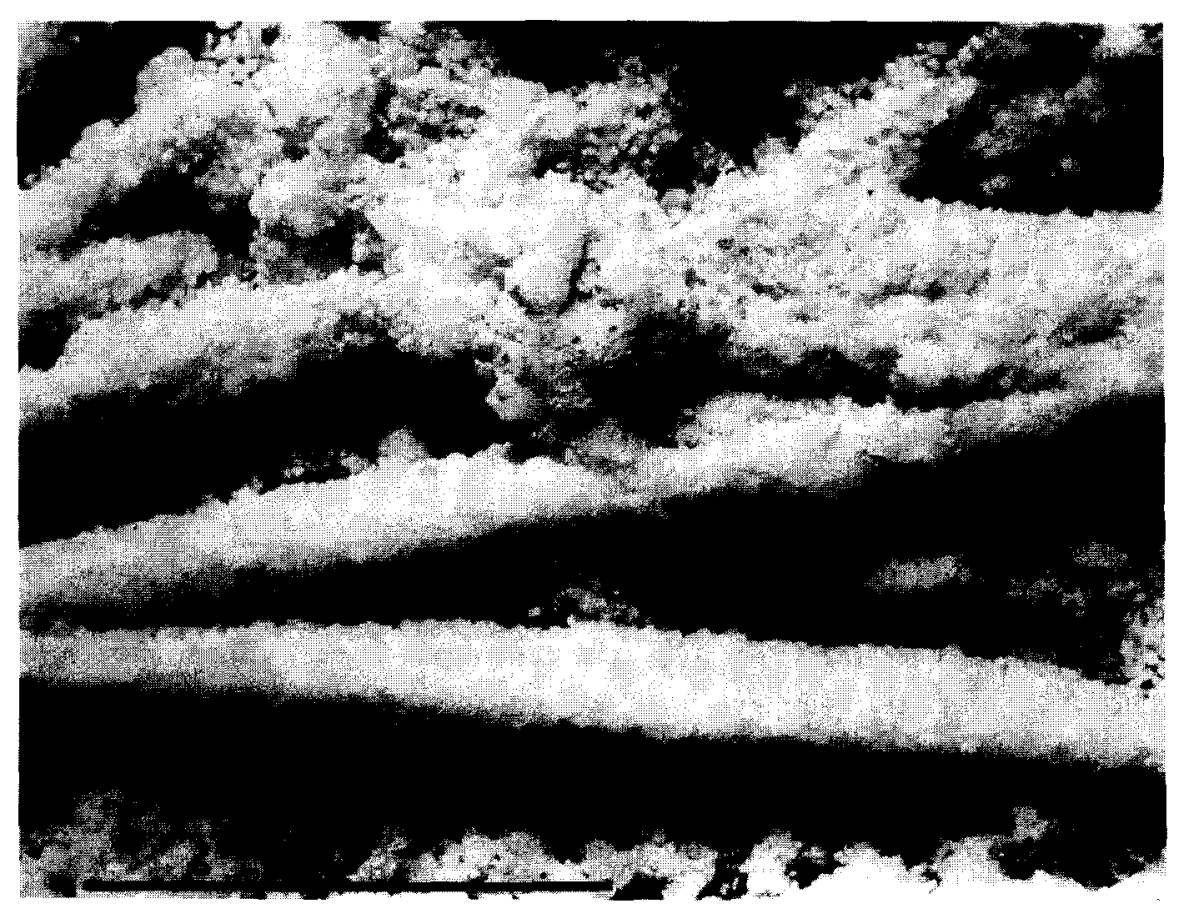

Fig. 7. Detail of crystals from a salt pan/playa in southern Saskatchewan. The long, acicular crystals are composed of bloedite and halite which have pseudomorphically replaced the original thenardite. Scale bar is $5 \mathrm{~cm}$. 
Post-depositional modification of these massive and bedded salts appears to have been extensive but little work has been done to document the diagenetic processes. Salt solution and karsting has been identified in numerous basins (Cole,
1926; Last, 1989), as has mud diapirism (Last and Slezak, 1987a). On a smaller scale, diagenetic alteration and replacement of metastable hydrated salts (often with equally metastable minerals) is common (Fig. 7 and Schweyen, 1984).
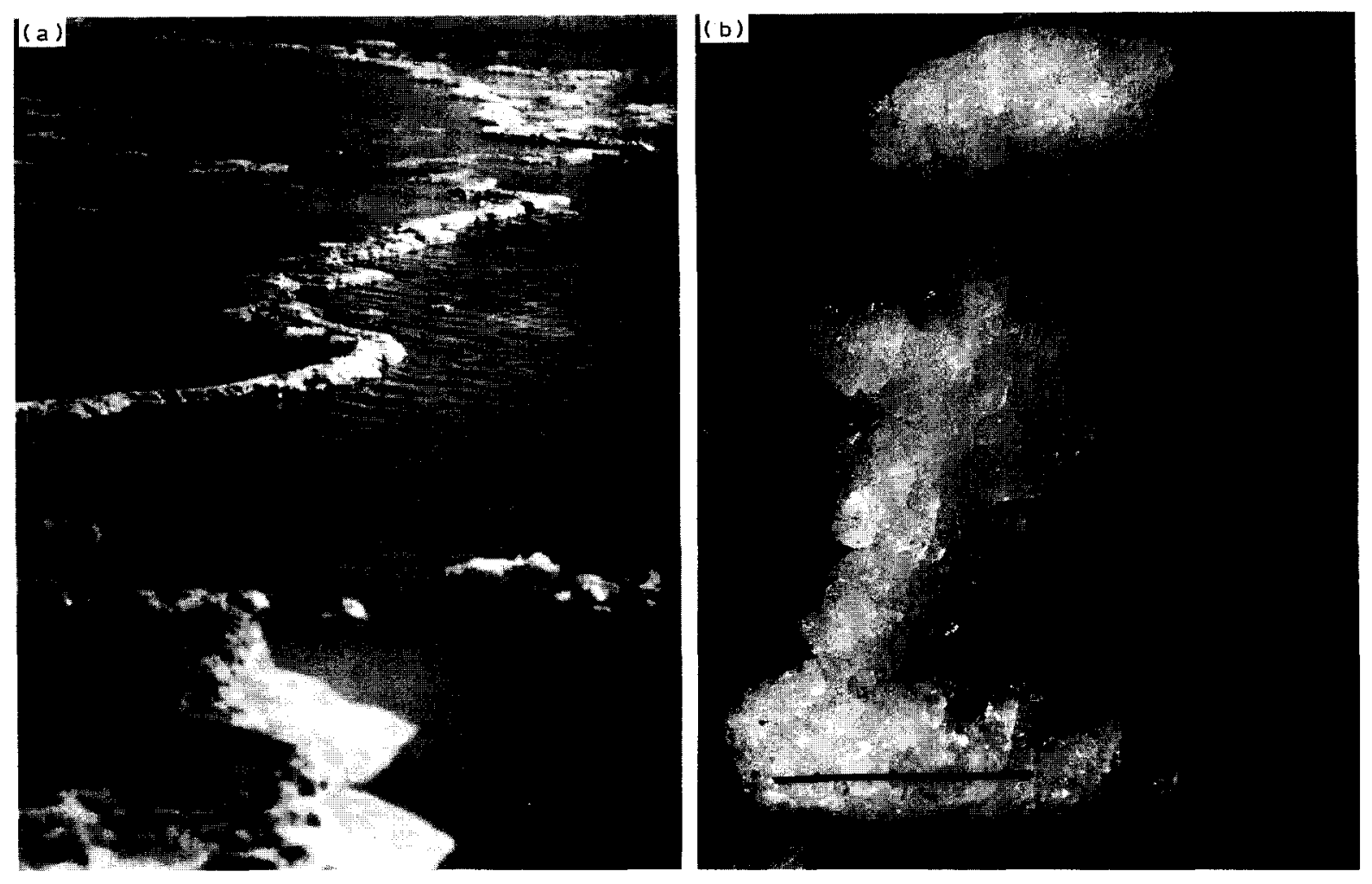

(c)

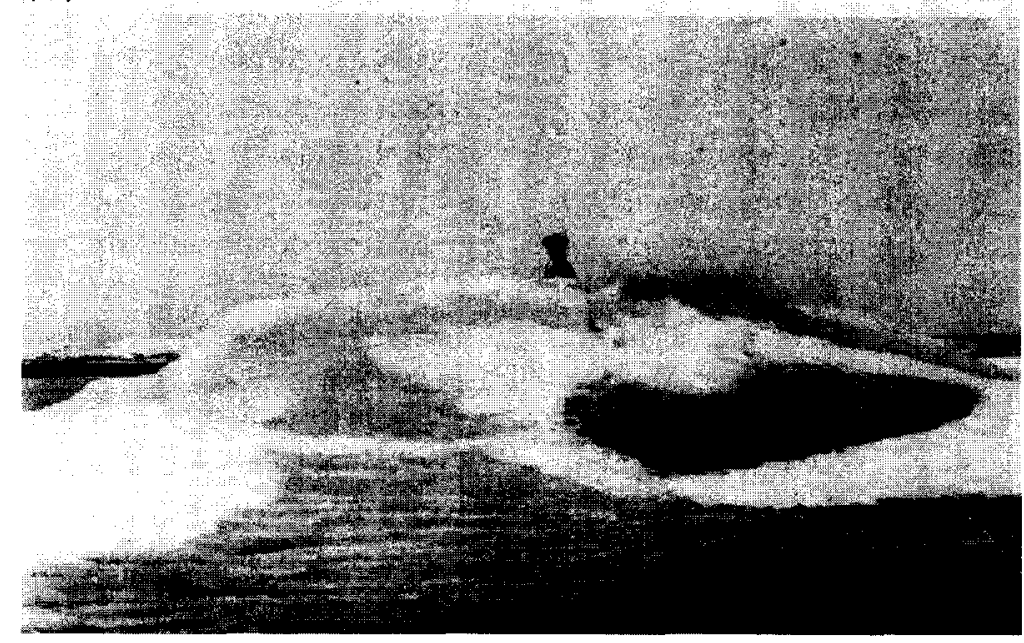

Fig. 8. Spring deposits associated with the salt lakes. (a) Sinter-like ridge composed of $\mathrm{Ca}$ and Na carbonates and sulfates near a brine spring discharge in Ceylon Lake, Saskatchewan. Ridge is approximately $10 \mathrm{~cm}$ wide. (b) A spring orifice accumulation composed of very soluble $\mathrm{Na}$ and $\mathrm{Na}-\mathrm{Mg}$ sulfates in Ceylon Lake. Scale bar is $20 \mathrm{~cm}$ long. (c) A $1.5 \mathrm{~m}$ high mound of crystal built up around the orifice of a brine spring during winter from Ingebright Lake, Saskatchewan (from Cole, 1926). 


\section{Spring deposits}

Although not strictly evaporites, travertine and tufa deposits do occur in several saline lakes of the Great Plains. Groundwater discharge along the eastern margin of Muskiki Lake in central Saskatchewan has built up carbonate mounds and terraces composed mainly of calcite and highmagnesium calcite several meters thick. Wave erosion of these mounds during high-water stages of the playa has created extensive carbonate beaches and shoals in the local vicinity. Large tufa deposits have also been reported from Metiskow Lake, Alberta (Cole, 1926). Last and Schweyen (1985) and Last (1989) identified sections of the early and mid-Holocene sediment records in Waldsea and Ceylon lakes having tufa-like fabrics and microtextures.

Somewhat more common than these carbonate mound and tufa accumulations are spring orifice and sheet-flood deposits composed of very soluble salts which occur in many of the salt lakes. Groundwater discharge is a very important component of the hydrologic budget of these saline lakes. Lake bottom springs are quite visible in most of the playa basins (Cole, 1926; Last, 1984) and equally evident in some of the perennial lakes. Because of temperature differences between the lake brine (which can reach $45^{\circ} \mathrm{C}$ on a warm, sunny day) and the much cooler discharging groundwater, saline springs can build sinter-like ridges and large cones (up to $3 \mathrm{~m}$ high) composed of soluble $\mathrm{Na}$ and $\mathrm{Mg}$ salts (Fig. 8a). Similarly, cold freshwater springs entering a sodium or magnesium sulfate lake can cool the brine sufficiently to produce massive spring orifice deposits of mirabilite and epsomite (Fig. 8b). Finally, in a playa setting, if the springs remain active during winter, laterally extensive sheet flood deposits and mounds of soluble salts (mirabilite, epsomite hydrohalite) can be precipitated on the frozen lake surface (Fig. 8c).

\section{Subsurface accumulations}

Salt mineral precipitation in each of the previous three types of evaporite occurrences takes place either subaerially or within a saturated water column of the lake. Although the resulting mineralogies can be complex (as is the case for desiccation of near surface groundwaters to form efflorescent crusts), in general these precipitates form rapidly and do not require any unusual mechanism other than simple evaporative concentration. A final type of evaporite mineral accumulation associated with the salt lakes occurs in the subsurface. Unfortunately, relatively little is known about the characteristics and genesis of this type of occurrence. There appears to be a gradation from single, isolated salt crystals growing displacively in the unconsolidated clastic sediments of playa mudflats to thick, laterally continuous beds of salt underlying entire basins.

Individual intrasedimentary crystals can vary in size from less than a micron to magnificent bladed or pyramidal crystals up to $10 \mathrm{~cm}$ in length. Occasionally clusters or pockets of crystals can be found, but most often they occur individually scattered throughout the muddy matrix. The mineralogy of these salts is dominated by mirabilite-thenardite, epsomite, and bloedite, although more rarely other precipitates can be found including scarbroite, dawsonite, kieserite, burkeite, and halite. Our knowledge of the vertical and lateral mineralogical distribution of these intrasedimentary salts in individual basins is still incomplete. In Lydden Lake, a small salt playa in central Saskatchewan, gypsum seems to be concentrated in the mudflat sediments at the basin margins, whereas the more soluble mirabilite and epsomite crystals dominate in the muds underlying the central part of the playa. Both the gypsum and the more soluble sulfates decrease in abundance with increasing depth until at about 5-6 m the muds are dominated by carbonate minerals and allogenic components (Lockhart, 1983; Lockhart and Last, 1984).

At the other end of the subsurface spectrum, laterally continuous and, in some cases, thick "sheets" of salts can be found within the stratigraphic sections of many of the playas of the region. These extensive, sheet-like accumulations differ from the previously described subsurface intrasedimentary salts in several ways:

(1) They are always composed mainly of mirabilite with few other ancillary evaporites. 


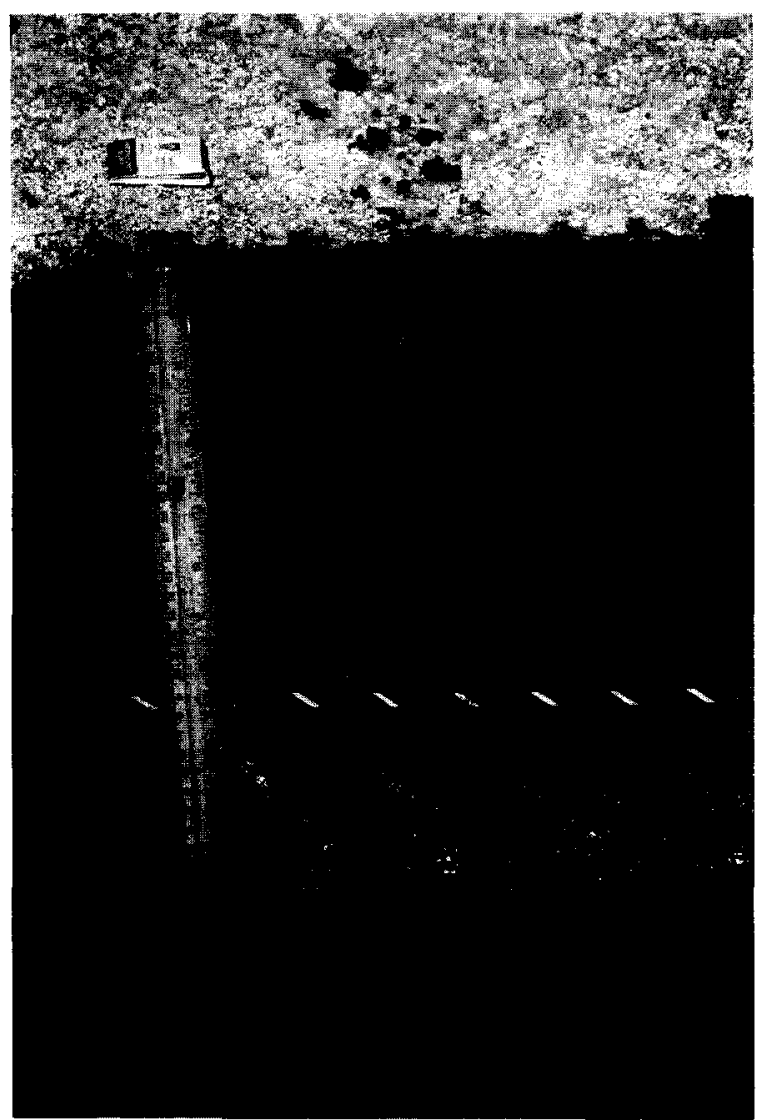

Fig. 9. Subsurface salt deposit at Corral Lake, Saskatchewan. Dashed line indicates the upper surface of the clastic-rich mirabilite accumulation. Ruler is $30 \mathrm{~cm}$ long.

(2) The deposits are usually clastic-rich; insoluble contents can be as high as $85 \%$.

(3) The salt is compact and hard, and shows a poikilotopic fabric.

(4) The upper surface of the accumulation usually occurs between 0.3 and $1 \mathrm{~m}$ below the surface of the playa (Fig. 9) and is constant across a given basin.

These subsurface salt beds can be in excess of 2 $m$ thick and sometimes extend laterally beyond the margins of the present-day lacustrine basin. They appear to be relatively common in the lakes of the Great Plains, but mapping of these features is difficult because of the lack of any surface indicators. Of the 25 sodium sulfate deposits described by Cole (1926), only four contained subsurface salt beds. In contrast, our reconnaissance drilling of mud-dominated playas in the Tompkins-Verlo area of southwestern Saskatchewan showed 8 out of 12 basins examined had this type of accumulation. Similarly, data supplied by Grossman (1949) and Binyon (1952) suggest that many playas in North Dakota have buried salt deposits.

The genesis of this mode of salt occurrence is not yet resolved. It is possible that the subsurface salt units were formed at the surface of a playa and subsequently buried by non-evaporitic playa muds. Alternatively, these salts may represent precipitation associated with a particular water table level or groundwater condition. Finally, the possibility that they are the result of illuviation by downward percolating playa waters must be considered.

\section{Process-product continuum in salt lakes}

The salt lakes of the northern Great Plains offer an excellent opportunity to examine the processes of continental evaporite deposition and diagenesis on both a local and regional scale. However, as is the case with most other depositional settings, the salt lakes exhibit a continuous spectrum of sedimentary regimes. This continuum exists in terms of nearly every parameter that can be evaluated for the basins: morphology, hydrology, degree of permanence, brine salinity and ionic composition, sediment character, etc. This great diversity presents somewhat of a problem in studying and discussing the lakes.

In an effort to divide up the continuum, several "end member" types of salt lakes can be recognized. A fundamental distinction must be made between those basins whose brines are shallow enough to permit periodic drying and those whose brines are deep enough to maintain a relatively permanent water body. The most significant processes operating in the shallow intermittent basins (playas) include: cyclic flooding and desiccation of the playa surface, formation of salt crusts, efflorescent crusts, hardgrounds, spring deposits, and intrasedimentary salts, formation of solution pits and karst features (chimneys), and periodic detrital sedimentation by sheet flow and wind. These processes are discussed in detail in Last $(1984,1989)$. 
In contrast, in the perennial lakes one of the most important features controlling sedimentation is stratification of the water column. The influence of seasonal temperature stratification on carbonate mineral saturation and equilibria in these lakes is well known (Last and Schweyen, 1983). The superposition of thermal stratification on an already chemically stratified (meromictic) water column greatly complicates mineral precipitation-dissolution reactions.

For example, in Deadmoose Lake both evaporitic and biogenically induced carbonate precipitation occurs in the well mixed, alkaline $(\mathrm{pH} \geqslant$ 8.5) epilimnion. Much of this carbonate materia however, is dissolved upon passing through the thermocline into the anoxic, lower $\mathrm{pH}(\leqslant 7.5)$ water of the hypolimnion, such that modern carbonate-rich muds are found only at water depths of less than $8 \mathrm{~m}$. In contrast, gypsum precipitation occurs in the water column below about 12 $\mathrm{m}$ depth and is preserved in the sediments of the monimolimnion. Although the surface waters become supersaturated with respect to $\mathrm{CaSO}_{4} \cdot 2 \mathrm{H}_{2} \mathrm{O}$ during the winter and gypsum precipitation occurs, sediment trap data indicate that this gypsum is re-dissolved before reaching the chemocline. Similarly, mirabilite precipitation occurs at the chemocline and in the surface water during winter. However, it is only preserved in the sediments of the monimolimnion at water depths of greater than $20 \mathrm{~m}$. Although this inhomogeneity can be relatively easily modelled once sufficient details are known about the chemical budgets of such a brine (e.g., Imboden and Lerman, 1978; Sloss, 1969; Schmalz, 1969), any interpretation of the stratigraphic record is made much more obscure because even subtle chemical and/or temperature changes can result in substantial changes in mineral precipitation and preservation.

\section{Source of salts and brine evolution}

The ultimate source of the ions in the salt lakes of the Great Plains has been a subject of considerable interest and debate but still remains enigmatic. The geographic coincidence of the lakes relative to the subsurface solution edge of the Devonian Prairie Evaporite Formation lead
Grossman (1968) to suggest that dissolution of these Palaeozoic evaporites by circulating groundwater may have provided the main source of ions. However, incompatible ionic ratios seem to argue against this hypothesis (Last and Slezak, 1987a). Some researchers working in North Dakota and Montana have suggested a source of salts from the shallower Tertiary Tongue River Formation (Sahinen, 1956; Witkind, 1959; Lemke, 1960, cited in Sloan, 1972), while many others contend that the glacial drift of the region could form an adequate supply of the necessary ions (e.g., Rozkowski, 1967; Rutherford, 1970; Sloan, 1972; Moran et al., 1978; Eilers, 1982). Cole (1926) considered the most likely source of $\mathrm{Na}$ in the salt lake brines to be from cation exchange ( $\mathrm{Ca}$ for $\mathrm{Na}$ ) on bentonitic clays of the glacial material. $\mathrm{He}$ attributes the sulfate to oxidation of pyrite in either the Cretaceous shales or glacial drift. In a detailed hydrogeological study of a small, closed basin in eastern Alberta, Wallick (1981) demonstrated that the chemistry of the shallow groundwater system (and, hence, the composition of the salt lake) can be accounted for by chemical weathering and leaching of mainly carbonate and silicate minerals in the surrounding glacial drift. The mineralogical sources of the major cations appear to be calcite, dolomite, plagioclase, illite and smectite clays. The major anions originate through oxidation of organo-sulfur compounds and pyrite, and soil/bacterial processes. Wallick and Krouse (1977) use $\delta^{32} \mathrm{~S}$ data to further confirm that the likely source of sulfate in the shallow groundwaters and lake is from oxidation of finely disseminated pyrite and organic matter in the drift.

While it is generally well accepted that groundwater plays an important role in supplying both water and ions to the salt lakes, quantitative evaluations of this role are lacking. Many researchers (e.g., Witkind, 1952; Rueffel, 1968; Freeze, 1969; MacWilliams and Reynolds, 1973) have noted the close association of many of the salt lakes of the region with buried glacial and preglacial valleys, and have concluded that these buried valleys act as conduits for groundwater supply to the lakes.

Definitive studies examining the chemical 
changes these inflowing waters undergo and the evaporative evolution of the lacustrine brines themselves are rare. Jones and van Denburgh (1966) and Owen et al. (1973) identify a sequence of decreasing $\mathrm{Ca}^{2+}$ and $\mathrm{HCO}_{3}^{-}$, and increasing $\mathrm{Mg}^{2+}, \mathrm{SO}_{4}^{2-}$, and TDS in the Devils Lake chain of basins in North Dakota. This chemical trend is presumably due to the precipitation of calcite, gypsum, and finally mirabilite sequentially through the chain of lakes. Similarly, Timpson et al. (1986) identify a calcite-gypsum-Na-Mg sulfate mineral precipitation sequence resulting from shallow groundwater migration upward through the sediments of saline seeps in western North Dakota. Hammer (1978) also postulates a general sequence of calcite and gypsum precipitation to account for the dominance of sodium, magnesium, and sulfate in the lacustrine brines of Saskatchewan.

Several additional factors must be considered when discussing the long-term evolution of these lacustrine brines. First, it must be realized that the lake basins and brine systems of the northern Great Plains are very young. Most of the basins in the region originated only about 10,000 years ago, in striking contrast to, for example, the much older salt lakes of Australia or the playas of southwestern United States.

Secondly, significant climatic changes during the Holocene may have interrupted or at least blurred the evolutionary sequence of the brines in many basins. Most of the present-day deep lakes of the Great Plains (for which paleoenvironmental data exist) were much shallower, or even periodically dry, during the mid-Holocene (Last and Slezak, 1988), resulting in precipitation of a variety of evaporitic $\mathrm{Ca}, \mathrm{Mg}$, and $\mathrm{Na}$ carbonates and sulfates. As climatic conditions moderated during the late Holocene and the hydrologic budgets became increasingly more positive, lake levels again rose. In some basins these higher water levels resulted in dissolution of at least the most soluble of the previously precipitated salts, giving rise to abruptly higher salinities and unusual brine chemistries (Last and Teller, 1983). In other basins, less dissolution took place and much of the soluble salt was preserved under sequences of organic-rich and carbonate-rich fresher-water muds, forming "inversely stratified" deposits.

\section{Summary}

Despite their economic and, in some cases, recreational importance for over 60 years, geological study of the salt lakes of the northern Great Plains is just beginning. These lakes offer an excellent opportunity to examine a wide range of sedimentological and evaporite mineral forming processes. The diversity of lacustrine chemical systems within this region gives rise to a great variety of endogenic and authigenic precipitates. Salt precipitation can occur in subaerial and periodically exposed settings, shallow water, and deep water environments. Four basic types of salt occurrences can be recognized based on genesis and stratigraphic setting: (a) surface crusts and hardgrounds, (b) massive and bedded salts, (c) deposits associated with springs, and (d) subsurface and groundwater-related accumulations. Our knowledge of the postglacial sedimentary records in these basins, although limited, does suggest that significant changes have occurred in brine composition during the last 10,000 years.

\section{Acknowledgements}

My sedimentological research on the lacustrine evaporitic environments of the northern Great Plains has been supported by grants from the Natural Science and Engineering Research Council of Canada; Energy, Mines and Resources of Canada; Canada Center for Inland Waters; the Canadian Plains Research Center; and the Max Bell Foundation. I thank the anonymous reviewers for their many helpful suggestions.

\section{References}

Barica, J., 1975. Geochemistry and nutrient regime of saline eutrophic lakes in the Erickson-Elphinstone district of southwestern Manitoba. Can. Fish. Mar. Serv, Res. Dev. Tech. Rep., 511: 82 pp.

Binyon, E.O., 1952. North Dakota sodium sulfate deposits. U.S. Bur. Mines, Rep. Invest., 4880: 41 pp.

Broughton, P.L., 1984. Sodium sulphate deposits of western Canada. In: G.R. Guillet and W. Martin (Editors), The Geology of Industrial Minerals in Canada. Can. Inst. Min. Metal., Spec. Vol., 29: 195-200. 
Callender, E., 1968. The postglacial sedimentology of Devils Lake, North Dakota. Ph.D. Thesis, University of North Dakota, Grand Forks, N.D., 312 pp.

Cameron, D.R., 1986. Saline Waters: agricultural Uses. In: D.T. Waite (Editor), Evaluation of Saline Waters in a Plains Environment. Canadian Plains Proc., 17: 75-107.

Clarke, F.W., 1924. The data of geochemistry. U.S. Geol. Surv. Bull., $770: 841$ pp.

Cole, L.H., 1926. Sodium sulphate of western Canada. Occurrence, uses and technology. Can. Dep. Mines, Publ,, 646: $160 \mathrm{pp}$.

Driver, E.A. and Peden, D.G., 1977. The chemistry of surface water in prairie ponds. Hydrobiology, 53: 33-48.

Eilers, J., 1982. Near surface glacial till stratigraphy and its effect on soil genesis. M.Sc. Thesis, University of Saskatchewan, Saskatoon, Sask., 249 pp.

Eugster, H.P. and Hardie, L.A., 1978. Saline lakes. In: A. Lerman (Editor), Lakes: Chemistry, Geology, Physics. Springer-Verlag, New York, N.Y., pp. 237-293.

Forbes, J.R. and Hickman, M., 1981. Paleolimnology of two shallow lakes in central Alberta, Canada. Int. Rev. Ges. Hydrobiol., 66: 863-888.

Freeze, R.A., 1969. Regional groundwater flow-Old Wives Lake drainage basin, Saskatchewan. Can. Inland Waters Dir. Sci. Ser., 5: 243 pp.

Ghebre-Egziabhier, K. and St. Arnaud, R.J., 1983a. Carbonate mineralogy of lake sediments and surrounding soils, 1. Blackstrap Lake. Can. J. Soil Sci., 63: 245-257.

Ghebre-Egziabhier, K. and St. Arnaud, R.J., 1983b. Carbonate mineralogy of lake sediments and surrounding soils, 2 . The Qu'Appelle Lakes. Can. J. Soil Sci., 63: 259-269.

Goudie, A.S. and Cooke, R.U., 1984. Salt efflorescences and saline lakes; a distributional analysis. Geoforum, 15: $563-582$

Govett, G.J.S., 1958. Sodium sulfate deposits in Alberta. Alta. Res. Counc., Prelim. Rep., 58-5: 34 pp.

Grossman, I.G., 1949. The sodium sulfate deposits of the western North Dakota: a progress report. N.D. Geol. Surv., Rep. Invest., I: $66 \mathrm{pp}$.

Grossman, I.G., 1968. Origin of sodium sulfate deposits of the northern Great Plains of Canada and the United States. U.S. Geol. Surv., Prof. Pap., 600-B: 104-109.

Hammer, U.T., 1978. The saline lakes of Saskatchewan, III. Chemical characterization. Int. Rev. Ges. Hydrobiol., 63: 311-335.

Hickman, M., Schweger, C.E. and Habgood, T., 1984. Lake Wabamun, Alta.: a paleoenvironmental study. Can. J. Bot., 62: $1438-1465$.

Imboden, D.M. and Lerman, A., 1978. Chemical models of lakes. In: A. Lerman (Editor), Lakes: Chemistry, Geology, Physics. Springer-Verlag, New York, N.Y., pp. 342-356.

Jones, B.F. and van Denburgh, A.S., 1966. Geochemical influences on the chemical character of closed lakes. In: Symposium of Garda, Hydrology of Lakes and Reservoirs, Proc. Int. Assoc. Sci. Hydrol. Publ., 70: 438-446.

Keller, C.P., McCarthy, G.S. and Richardson, J.L., 1986.
Mineralogy and stability of soil evaporites in North Dakota. Soil Sci. Soc. Am., J., 50: 1069-1071.

Last, W.M., 1982. Holocene carbonate sedimentation in Lake Manitoba, Canada. Sedimentology, 29: 691-704.

Last, W.M., 1984. Sedimentology of playa lakes of the northern Great Plains. Can. J. Earth Sci., 21: 107-125.

Last, W.M., 1988. Salt lakes of western Canada: a spatial and temporal geochemical perspective. In: W. Nicholaichuk and H. Steppuhn (Editors), Proc. Symp. on Water Management Affecting the Wet-to-Dry Transition. Water Studies Institute, Saskatoon, Sask., pp. 99-113.

Last, W.M., 1989. Sedimentology of a saline playa in the northern Great Plains, Canada. Sedimentology, 36: 109-123.

Last, W.M. and Schweyen, T.H., 1983. Sedimentology and geochemistry of saline lakes of the northern Great Plains. Hydrobiology, 105: 245-263.

Last, W.M. and Schweyen, T.H., 1985. Late Holocene history of Waldsea Lake, Saskatchewan, Canada. Quat. Res., 24: 219-234.

Last, W.M. and Slezak, L.A., 1986. Paleohydrology, sedimentology, and geochemistry of two meromictic saline lakes in southern Saskatchewan. Géogr. Phys. Quat., XL: 5-15.

Last, W.M. and Slezak, L.A., 1987a. Sodium sulphate deposits of western Canada: geology, mineralogy, and origin. In: M. Thomas and L. Vigrass (Editors), Economic Minerals of Saskatchewan. Sask. Geol. Soc., Spec. Publ., 9: 197-205.

Last, W.M. and Slezak, L.A., 1987b. Geolimnology of an unusual saline lake in the Great Plains of western Canada. In: A.R. Chivas and P. De Deckker (Editors), Proceedings of SLEADS 87 Workshop. Australian National University. p. 9-11.

Last, W.M. and Slezak, L.A., 1988. The salt lakes of western Canada: a paleolimnological overview. Hydrobiology 158 : 301-316

Last, W.M. and Teller, J.T., 1983. Holocene climate and hydrology of the Lake Manitoba basin. In: J.T. Teller and L. Clayton (Editors), Glacial Lake Agassiz. Geol. Assoc. Can., Spec. Pap., 26: 333-353.

Lemke, R.W., 1960. Geology of the Souris River area, North Dakota. U.S. Geol. Surv., Prof. Pap., 325: 138 pp.

Lockhart, E.B., 1983. Origin of gypsum in Lydden Lake, Saskatchewan B.Sc. Thesis, University of Manitoba, Winnipeg, Manit., 57 pp. (unpublished).

Lockhart, E.B. and Last, W.M., 1984. Sedimentology and geochemistry of a small salt playa in southern Saskatchewan. Geol. Assoc. Can., Progr. Abstr., 9: 84.

MacDonald, D.E., 1982. Marl resouces of Alberta. Alta. Res. Counc., Earth Sci. Rep., 82-1: 94 pp.

MacWilliams, R.W. and Reynolds, R.G., 1973. Solution mining of sodium sulfate. Can Inst. Min. Metall., Trans., LXXVI: 127-131.

Moore, G.E., 1939. A limnological study of certain lakes of southern Saskatchwan, with special reference to salinity. M.A. Thesis, University of Saskatchewan, Saskatoon, Sask., $40 \mathrm{pp}$. 
Moran, S.R., Groenewold, G.H. and Cherry, J.A., 1978. Geologic, hydrologic and geochemical concepts and techniques in characterization for mined-land reclamation. N.D. Geol. Surv., Rep. Invest., 63: 152 pp.

Owen, J.B., Tubb, R., Anderson, D.W. and Callender, E., 1973. The biogeochemistry of Devils Lake, North Dakota. U.S. OWRR Project Rep., A-006-NDAK, 83 pp.

Rawson, D.S. and Moore, G.E., 1944. The saline lakes of Saskatchewan. Can. J. Res., Sect. D, 22: 141-201.

Rozkowska, A.D. and Rozkowski, A., 1969. Seasonal changes of slough and lake water chemistry in southern Saskatchewan, Canada. J. Hydrol., 7: 1-13.

Rozkowski, A., 1967. The origin of hydrochemical patterns in hummocky morain. Can. J. Earth Sci., 4: 1065-1092.

Rueffel, P.G., 1968. Development of the largest sodium sulfate deposit in Canada. Can. Min. Metall., Bull., 61: 1217-1228.

Rutherford, A.A., 1970. Water quality survey of Saskatchewan Surface Waters. Sask. Res. Counc., Rep., C-70-1: 133 pp.

Sahinen, U.M., 1956. Preliminary report on sodium sulphate in Montana. Bur. Mines Geol. Invest., Circ., 11: 9 pp.

Schmalz, R.F., 1969. Deep-water evaporite deposition: a genetic model. Am. Assoc. Pet. Geol. Bull., 53: 798-823.

Schwartz, F.W. and Gallup, D.N., 1978. Some factors controlling the major ion chemistry of small lakes: examples from the prairie parkland of Canada. Hydrobiology, 58: 65-81.

Schweyen, T.H., 1984. Sedimentology and paleohydrology of Waldsea Lake, Saskatchewan. M.Sc. Thesis, University of Manitoba, Winnipeg, Manit., 111 pp.

Slezak, L.A. and Last, W.M., 1985. Geology of sodium sulfate deposits of the northern Great Plains. In: J.D. Glass and J. Edwards (Editors), Twentieth Forum on the Geology of Industrial Minerals. Md. Geol. Surv., Spec. Publ., 2: 105-115.

Sloan, C.E., 1972. Groundwater hydrology of prairie potholes in North Dakota. U.S. Geol. Surv., Prof. Pap., 585-C: 28 pp.
Sloss, L.L., 1969. Evaporite deposition from layered solutions. Am. Assoc. Pet. Geol. Bull., 53: 776-789.

Timpson, M.E. and Richardson, J.L., 1986. Ionic composition and distribution in saline seeps of southwestern North Dakota, U.S.A. Geoderma, 37: 295-305.

Timpson, M.E., Richardson, J.L., Keller, L.P. and McCarthy, G.J., 1986. Evaporite mineralogy associated with saline seeps in southwestern North Dakota. Soil Sci. Soc. Am. J., 50: $490-493$.

Tomkins, R.V., 1953. Magnesium in Saskatchewan. Sask. Dep. Miner. Resour., Rep., 11: 23 pp.

Tomkins, R.V., 1954. Natural sulfate in Saskatchewan. Sask. Dep. Miner. Resour., Rep., 6: 71 pp. (2nd ed.).

Wallick, E.I., 1981. Chemical evolution of groundwater in a drainage basin of Holocene age, east central Alberta, Canada. J. Hydrol., 54: 245-283.

Wallick, E.I. and Krouse, H.R., 1977. Sulphur isotope geochemistry of a groundwater generated $\mathrm{Na}_{2} \mathrm{SO}_{4} / \mathrm{Na}_{2} \mathrm{CO}_{3}$ deposit and the associated drainage basin of Horseshoe Lake, Metiskow, east-central Alberta, Canada. Proc. 2nd Int. Symp. Water-Rock Interaction, Strasbourg, pp. 1156-1164.

White, G.R. and Hartland-Rowe, R., 1969. Temporal changes of physical and chemical factors in a shallow astatic saline lake. Verh. Int. Verein. Limnol., 17: 440-446.

Winter, T.C., 1977. Classification of the hydrologic setting of lakes in the North Central United States. Water Resour. Res., 13: 753-767.

Witkind, I.J., 1952. The localization of sodium sulfate deposits in northeastern Montana and northwestern North Dakota. Am., J. Sci. 250: 667-676.

Witkind, I.J., 1959. Quaternary geology of the Snake Creek-Medicine Lake-Grenora area, Montana and North Dakota. U.S. Geol. Surv., Bull., 1073: 80 pp. 